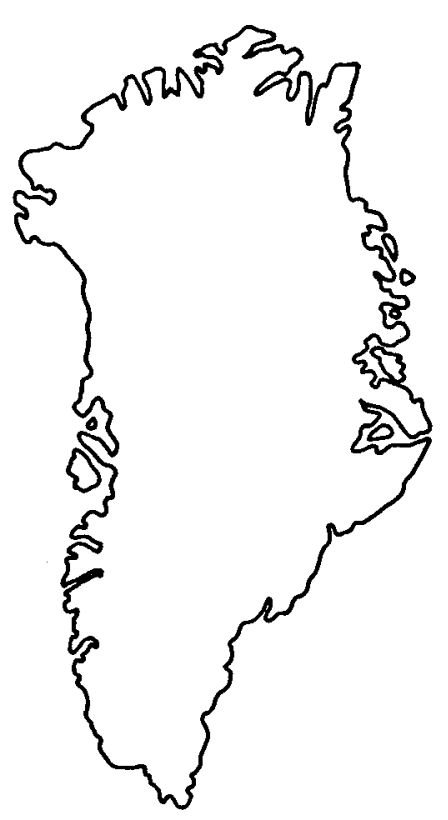

\title{
A new genus of nevadiid trilobite from the Buen Formation (Early Cambrian) of Peary Land, central North Greenland
}

\author{
Mark R. Blaker
}

\begin{abstract}
A new genus of nevadiid trilobite is described from the Lower Cambrian of Peary Land, central North Greenland, from the same horizon and locality from which a non-skeletised fauna has been recently reported. The new genus, Buenellus, is tentatively assigned to the Nevadiidae Hupé, 1953, and comparisons are made with the genera Nevadia Walcott, 1910, Nevadella Raw, 1936, Callavia Matthew, 1897, Holmia Matthew, 1890 and Kjerulfia Kiaer, 1917.
\end{abstract}

M. R. B., Department of Geology, University of Keele, Staffordshire STS $5 B G, U . K$.

Conway Morris et al. (1987) recently reported a new non-skeletised fauna from the Lower Cambrian of North Greenland having many similarities with the Middle Cambrian Burgess Shale fauna from British Columbia, Canada. The new fauna was collected from the upper part of the Buen Formation from a single locality near J. P. Koch Fjord, western Peary Land (figs 1,2). The Buen Formation has been interpreted as a siliciclastic shelf sequence with a

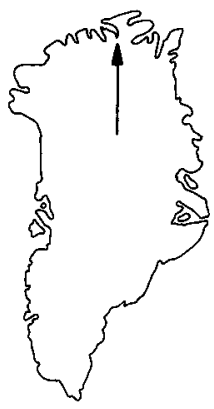

Fig. 1. Locality map.

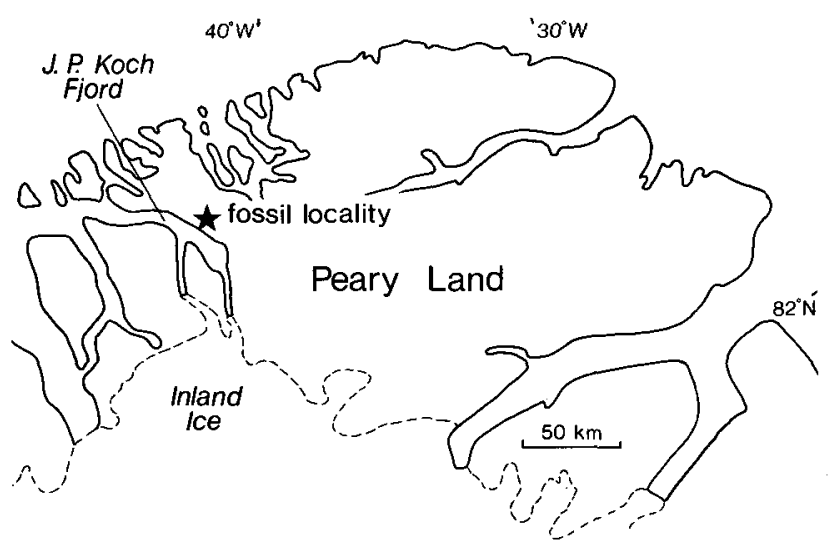

Rapp. Grønlands geol. Unders. 137, 33-41 (1988) 


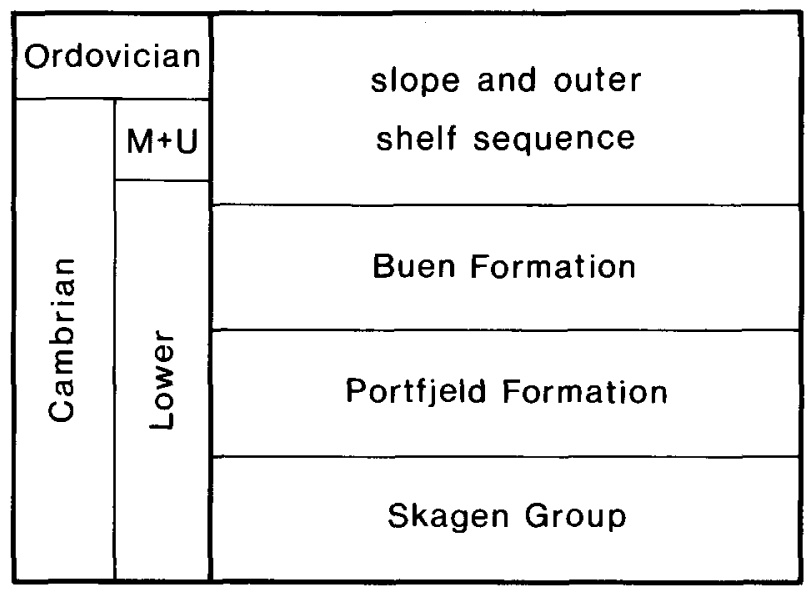

Fig. 2. Cambrian stratigraphy in western Peary Land.

lower sandstone unit deposited under high energy, inshore conditions succeeded by an upper, mainly mudstone unit, deposited in a lower energy, outer shelf environment (Jepsen, 1971; Peel, 1982; Higgins et al., in press). Occurring with the non-skeletised fauna in the deeper water mudstones is a nevadiid trilobite which is described below.

Order Olenellida Resser, 1938

Superfamily Olenellacea Vogdes, 1893

?Family Nevadiidae Hupé, 1953

Genus Buenellus gen. nov.

Derivation of name. From the Buen Formation.

Diagnosis. Nevadiid with elongate glabella tapering gently forward, not reaching border. Wide (sag.) occipital ring. Palpebral lobes of moderate length (exsag.), narrow (tr.); widening as approaching glabella. Wire-like intergenal and metagenal ridges meet at posterior border at position of intergenal spine. Short, stout genal spines, not advanced. The border and border furrow are weakly defined anteriorly and antero-laterally. Thorax and pygidium of 19 segments of which the pygidium usually forms only the posterior-most segment. Thorax tapers rapidly, posteriorly of the eighth segment. Pleurae sigmoidally curved with short deep furrow. Axial rings with medial node. Pygidium formed of single plate.

Discussion. In the past 15 years several revisions of olenellid classification have been made. Bergström (1973) recognized three families and placed Nevadia Walcott, 1910, Nevadella Raw, 1936, Callavia Matthew, 1897 and Kjerulfia Kiaer, 1917 in the Daguinaspididae Hupé, 1953, and Holmia Matthew, 1890 in the Holmiidae Hupé, 1953. Subsequently Repina (1979) split the Daguinaspididae (sensu Bergström) into four families. She placed Nevadia and Nevadella in the Nevadiidae Hupé, 1953, and it is to this family that I tentatively assign the new genus Buenellus. Repina assigned Holmia, Callavia and Kjerulfia to the Holmiidae 
Hupé, 1953. Ahlberg et al. (1986, p. 40) largely accepted Repina's classification, but it was their opinion that Callavia should be assigned to their new family Callaviidae.

The material from the Buen Formation resembles Nevadella Raw, 1936. This genus, however, has much longer (exsag.) and wider (tr.) ocular lobes, that extend back to the level of the occipital ring, and has genal spines that extend back beyond this level. In addition Nevadella lacks the intergenal and metagenal ridges, as well as intergenal spines. The thorax of Nevadella is known to have from 18 to 23 segments; it lacks macropleural segments, and the pygidium is small. In these features Buenellus is similar to Nevadella.

Nevadia Walcott, 1910 has very wide (tr.) extraocular cheeks, a strongly furrowed glabella and lacks metagenal ridges. The ocular lobes are of similar length but are much wider (tr.) than in Buenellus, with intergenal ridges extending from their posterior tip. The thorax is considerably different from that of Buenellus having 28 segments, with the pleurae extending into long curved spines. The pygidia, however, are similar. The development of an intergenal spine and ridge are characteristic of species assigned to Callavia Matthew, 1897. For Callavia species, however, the position of this spine is different from that in Buenellus, being very close to the genal angle, and no metagenal ridge is developed. Additionally the ocular lobes are more strongly crescentic, and of greater relative length in Callavia. In the type species C. bröggeri (Walcott, 1888) the occipital ring bears a long, backwards directed, slender spine. On all species assigned to the genus the glabella has four or five welldeveloped pairs of furrows. The thorax and pygidium are similar to those of the new North Greenland material with up to 18 segments in the thorax, each with short, stout, posterolaterally-directed spines, a pleural furrow that extends over the adaxial half of the pleura and axial rings with a short median node. The pygidium is formed of a single plate with a short median spine on the posterior margin.

Buenellus shows some similarities to Holmia Matthew, 1890 in that for both genera the cephalic border is poorly-defined in front of the glabella and metagenal and intergenal ridges are present. In general, like Buenellus, species of Holmia do not have macropleural thoracic segments, and the distance from the axis to the pleural fulcrum is short. The glabella in Holmia, however, is strongly furrowed, and the expanded anterior lobe extends to the anterior border. The palpebral lobes of Holmia species are considerably wider (tr.), and often marked by an epipalpebral furrow. In the type species, $H$. kjerulfi (Linnarsson, 1871), the thorax is formed of 16 segments which taper regularly backwards, and have welldeveloped axial spines posterior to the tenth segment. The pygidium of Holmia is unlike that of Buenellus, being formed of at least two segments and a terminal piece. Both intergenal and metagenal ridges are developed in species of Kjerulfia Kiaer, 1917; these converge on the posterior border at the position of an intergenal spine or node. The taxonomic importance of intergenal and metagenal ridges is uncertain for they are present in genera assigned to different families, for example Fallotaspis Hupé, 1953 and Kjerulfia. Kjerulfia differs from Buenellus in having much wider (tr.) ocular lobes, and a strongly-furrowed glabella. In addition, the cephalic border is wider. The thorax of Kjerulfia has up to 17 segments with distinct medial axial nodes that increase in length posteriorly from the twelth segment, with the posterior two axial rings possessing long, slender spines. The pygidium is comparable in form to Buenellus. 
Buenellus higginsi sp. nov.

Figs 3-6, Table 1

Derivation of name. For A. K. Higgins who collected the material.

Holotype. MGUH 18.287 from GGU sample 319571.

Figured paratypes. MGUH 17.585-17.590, all from GGU sample 319571.

Other material. GGU 319571.1-10 (damaged complete specimens), GGU 319571.11-13 (partial cephalon and thorax), GGU 319571.14-16 (partial thorax-pygidium).

Diagnosis. As for genus.

Description. Cephalon semicircular in outline. Elongate glabella tapers gently forward with rounded anterior; it is of low convexity transversely, whilst sagittally the posterior threequarters are horizontal on average with the anterior quarter sloping gently downward to the preglabellar field. Occipital ring wide (sag.), horizontal and slightly below level of rest of glabella; sagittal length approximately one-quarter that of glabella. S0 moderately concave posteriorly, being of medium depth distally, shallowing over sagittal line. Posterior margin of occipital ring has similar curvature to S0. No apparent occipital spine or node. Up to three pairs of glabellar furrows are developed, although on most specimens it is only the posterior pair that are visible. S1 of moderate length, directed moderately backwards, not connected across glabella but joined to axial furrow. S2 shorter than S1, directed backwards at a similar angle and of about equal depth. S3 only observed on one specimen (fig. 3B), a shallow expanded furrow shorter than S2. Exsagittal length of lateral glabellar lobes decreases forwards. Glabella defined by narrow (tr.) furrow which is weakly to moderately impressed. Glabella anteriorly separated from border by narrow (sag.) preglabellar field with a sagittal length of about one-fifth that of glabella. Transverse width of intraocular areas between three-eighths and two-fifths of basal glabellar width. Intraocular areas slope gently outward. Palpebral lobes of moderate length (exsag.), narrow (tr.), gently arcuate and centered slightly forward of S1. Palpebral lobes are defined by shallow and narrow (tr.) furrow, or by

\begin{tabular}{ccrrrrr}
\hline & \multicolumn{2}{c}{ Fig. 3 } & \multicolumn{2}{c}{ Fig. 4 } & \multicolumn{2}{c}{ Fig. 5 } \\
Specimens & A & B & A & B & A & B \\
\hline \multicolumn{2}{l}{ Measurements } \\
1 & 34.9 & 26.2 & 26.3 & 67.8 & 44.1 & 45.2 \\
2 & 11.6 & 9.6 & 11.1 & 22.5 & 15.8 & 16.25 \\
3 & 21.8 & 15.5 & - & 42.1 & 27.2 & 27.2 \\
4 & 1.5 & 1.1 & - & 3.2 & 1.1 & 1.75 \\
5 & - & 14.2 & 19.4 & 34.3 & 23.4 & 29.6 \\
6 & 6.15 & 4.5 & 6.1 & 11.0 & 8.1 & 8.25 \\
7 & 10.5 & 7.9 & 9.3 & 18.6 & 13.9 & 13.75 \\
\hline
\end{tabular}

Measurements. 1, sagittal length; 2, sagittal cephalic length; 3, sagittal thoracic length; 4, sagittal pygidial length;

5 , maximum transverse width of cephalon; 6 , basal glabellar width; 7, sagittal glabellar length. All measurements are in millimetres.

Table 1. Dimensions of Buenellus higginsi gen. et sp. nov. 

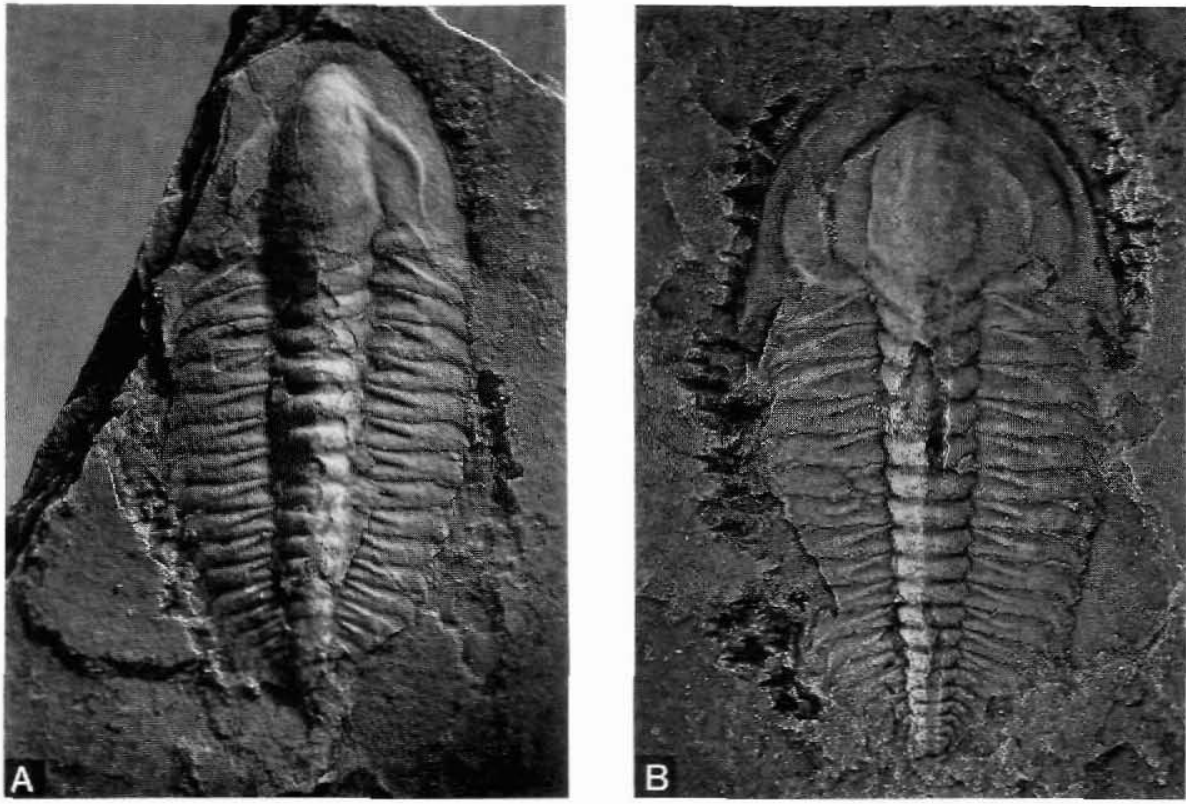

Fig. 3. Buenellus higginsi gen. et sp. nov. Buen Formation, GGU sample 319571. A, MGUH 17.586. Paratype damaged complete specimen; dorsal view. $\times 2$. B, MGUH 18.287. Holotype damaged complete specimen; dorsal view. $\times 2.6$.
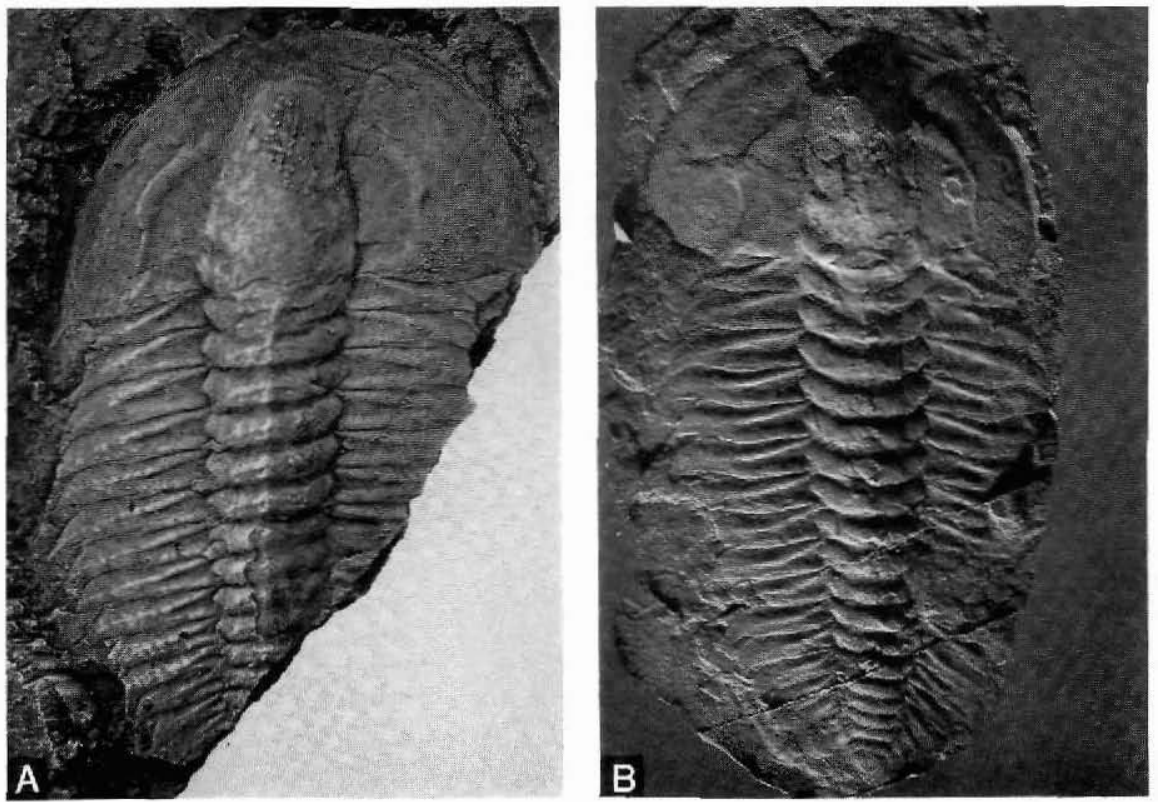

Fig. 4. Buenellus higginsi gen. et sp. nov. Buen Formation, GGU sample 319571. A, MGUH 17.587. Paratype damaged complete specimen; dorsal view. $\times$ 2. B, MGUH 17.588. Paratype damaged complete specimen; dorsal view. $\times 1.3$. 

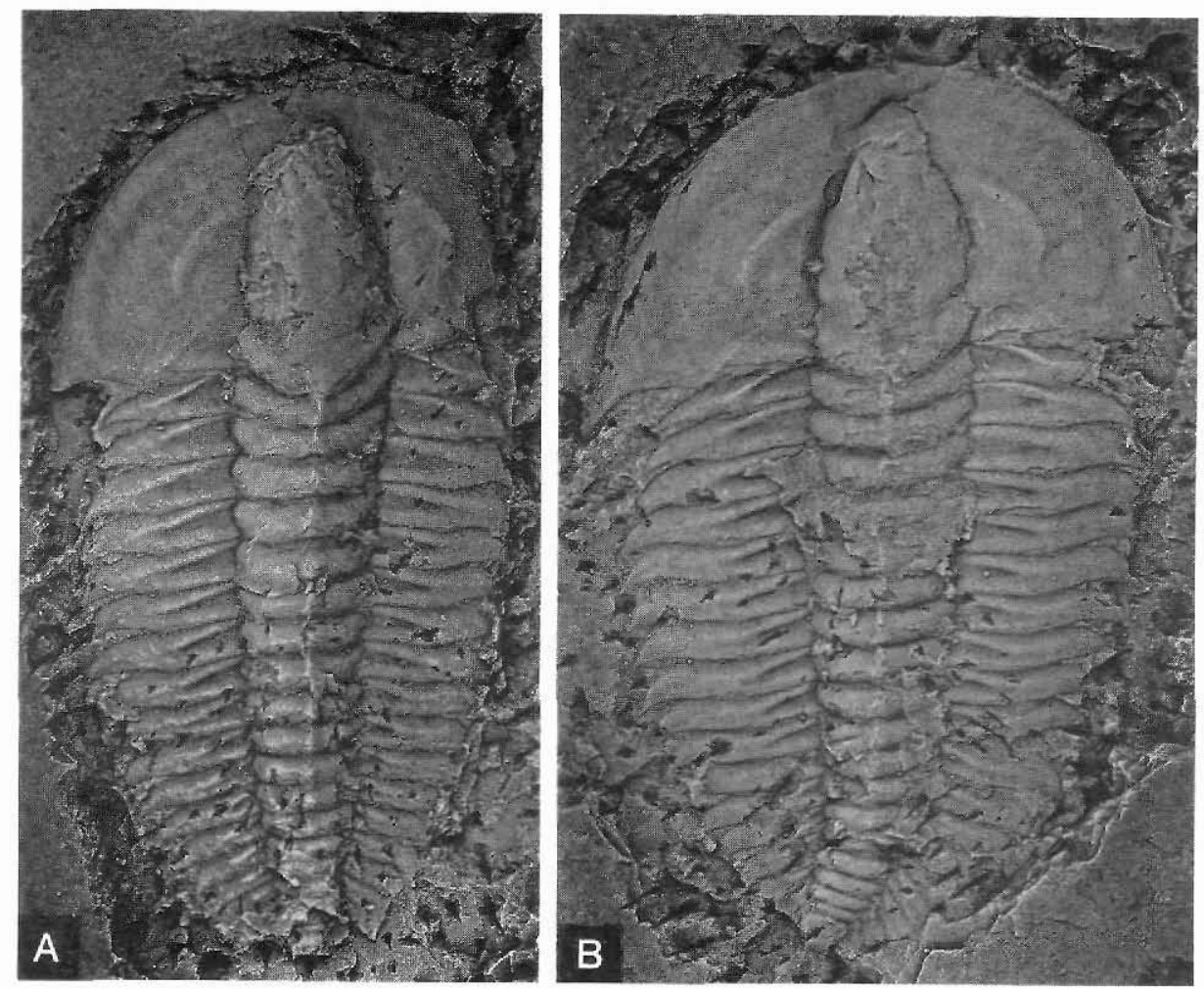

Fig. 5. Buenellus higginsi gen. et sp. nov. Buen Formation, GGU sample 319571. A, MGUH 17.589. Paratype damaged complete specimen; dorsal view. $\times 2$. B, MGUH 17.590. Paratype damaged complete specimen; dorsal view. $\times 2$. Both specimens have well-developed intergenal and metagenal ridges, and short genal spines. On specimen $\mathrm{B}$ the pygidium is formed of a single plate crossed by a transverse furrow.

change in slope of exoskeleton. No apparent differentiation into ocular ridge with the palpebral lobes widening (exsag.) as they approach the glabella. Exsagittal length of lobés approximately two-fifths of sagittal glabellar length. Low narrow (tr.) intergenal ridge extends from posterior tip of ocular lobe backwards at an angle of 70 degrees to border. From the same position on the border a low straight metagenal ridge is directed forward at an angle of about 60 degrees to an exsagittal line to the glabella, which it joins slightly anteriorly of S0. The two ridges meet at the position of the intergenal spine which is marked by a slight swelling of the border. Extraocular cheeks gently convex (tr.), sloping moderately outwards. Anterior margin of cephalon evenly curved and continuous along short, stout, postero-laterally-directed genal spine. Posterior border directed gently postero-laterally from axis until position of intergenal spine, then slightly antero-laterally to base of genal spine. Weakly defined border of moderate width and border furrow are even less well defined anteriorly and antero-laterally.

Thorax usually formed of 18 segments (but see discussion below) with no macropleural segments. Posteriorly of the eighth segment the thorax tapers rapidly; anteriorly over 

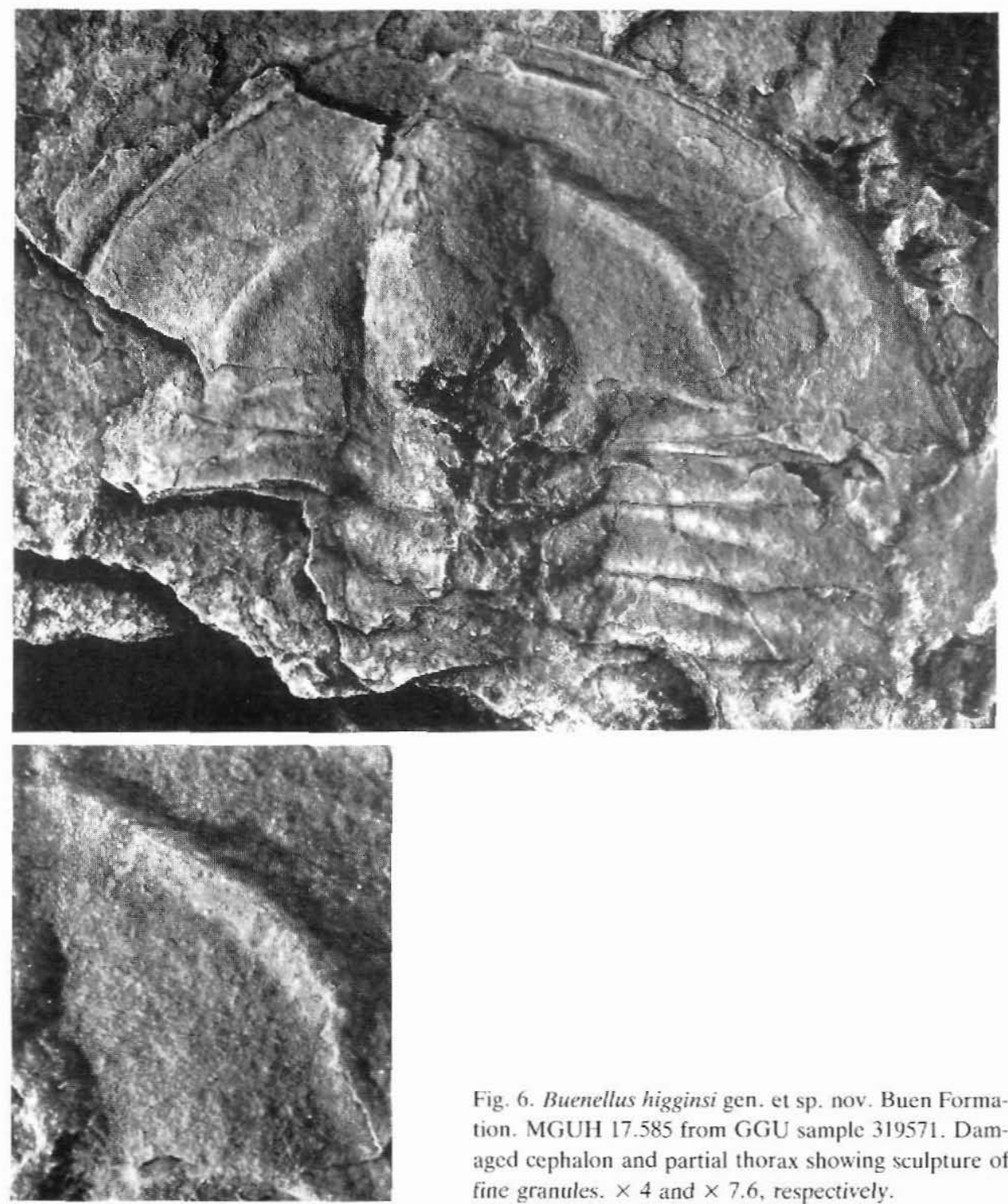

Fig. 6. Buenellus higginsi gen. et sp. nov. Buen Formation. MGUH 17.585 from GGU sample 319571. Damaged cephalon and partial thorax showing sculpture of fine granules. $\times 4$ and $\times 7.6$, respectively.

segments $1-8$ there is a slight widening of the thorax. Axial rings of moderate convexity (tr.), with axis defined by narrow (tr.) furrow. Posterior margins of axial rings variable from straight transverse to gently concave posteriorly. Lateral margins of axial rings moderately curved outwards. Rings have a median node, often elongated along the sagittal line. Transverse width of ring approximately one-third width of corresponding segment. Pleurae gently sigmoidal in plan view; adaxial half directed gently postero-laterally, abaxial half initially antero-laterally then extended into postero-laterally-directed broad, stout spine. Each pleura marked by wide (exsag.) furrow of medium depth that extends over adaxial 
half. The anterior ridge extends into a spine on some specimens, whilst the posterior ridge ends at the fulcrum. The more posterior segments have a relatively shorter pleural furrow being only one-third the pleural length. Pleurae become directed more strongly posteriorly from the tenth segment backwards. Pleurae very slightly convex (tr.), sloping outwards from axial furrow.

Pygidium usually formed of a single plate that is subtriangular in outline, gently convex (tr. and sag.) and sloping moderately backwards. A transverse furrow that is concave posteriorly and of medium depth, crosses the pygidium.

Sculpture is of fine granules covering all parts of the exoskeleton. This is particularly well developed on a deformed specimen of an incomplete cephalon and thorax (fig. 6), although most specimens do not show any preserved sculpture.

Discussion. Within the small population available for study some variability of morphology has been observed. Specimens are flattened, and as the amount of distortion can not be determined, the relative convexities of the exoskeleton are not necessarily those of undeformed material. As mentioned in the description, above, there is variation in the number of pairs of glabellar furrows between one and three, which is presumably mainly a preservational effect. Additionally the form of these furrows is not consistant, being diffuse and shallow in some specimens and more slot-like in others. On the axial rings a convex, transverse marking is often apparent; I have interpreted this marking as the impression of the underlying articulating half-ring, which is visible due to compression of the specimen. As described above, the pygidium is usually composed of a single subtriangular plate bearing a transverse furrow. On at least two specimens, however, (one of which is illustrated in fig. 4B) it appears that the final thoracic segment is still retained in the pygidium, despite the considerable sagittal length of the specimens. For these specimens the pygidium is formed of the unreleased segment bearing short, unfurrowed spines that are directed strongly backwards, and the terminal plate. The plate is separated from the unreleased segment by an incomplete furrow that is represented distally by moderately deep pits. It is noted that these specimens with only 17 segments in the thorax, have sagittal lengths greater than those of several specimens with 18 ; the condition therefore is not merely a feature associated with late meraspids, but rather with variation within the holaspid.

The new form affords no new biostratigraphic information; as discussed by Palmer \& Peel $(1979$, p. 33$)$ the Buen Formation is considered as being of middle to late Early Cambrian age, with the lower part of the overlying Brønlund Fjord Group yielding late Early Cambrian faunas (Palmer \& Peel, 1979; Peel, 1982; Blaker, 1986). In North America this would correlate with the upper part of the Nevadella Zone or the lower part of the overlying Bonnia-Olenellus Zone.

Acknowledgements. The support of N.E.R.C. Research Studentship GT4/84/GS/37 is gratefully acknowledged. A. K. Higgins kindly made the material available for study. I thank P. D. Lane and V. Poulsen for reading earlier versions of this manuscript, and for suggesting improvements. Per Ahlberg gave advice on the taxonomy. John Peel provided figs 1 and 2 . 


\section{References}

Ahlberg, P., Bergström, J. \& Johansson, J. 1986: Lower Cambrian olenellid trilobites from the Baltic Faunal Province. Geol. Fören. Stockh. Förh. 108, 39-56.

Bergström, J. 1973: Classification of olenellid trilobites and some Balto-Scandian species. Norsk geol. Tidsskr. 53, 283-314.

Blaker, M. R. 1986: Notes on the trilobite faunas of the Henson Gletscher Formation (Lower and Middle Cambrian) of central North Greenland. Rapp. Grønlands geol. Unders. 132, 65-73.

Conway Morris, S., Peel, J. S., Higgins, A. K., Soper, N. J. \& Davis, N. C. 1987: A Burgess shale-like fauna from the Lower Cambrian of North Greenland. Nature 326, 181-183.

Higgins, A. K., Ineson, J. R., Peel, J. S., Surlyk, F. \& Sønderholm, M. in press: The Franklinian basin in North Greenland. In Trettin, H. P. (edit.) The Innuitian region. The Geology of North America vol. E. Ottawa: Geol. Surv. Canada.

Hupé, P. 1953: Contribution à l'étude de Cambrien inférieur et du Précambrien III de l'Anti-Atlas marocain. Service géol. Maroc, Notes et Mem. 103, $402 \mathrm{pp}$.

Jepsen, H. F. 1971: The Precambrian, Eocambrian and early Palaeozoic stratigraphy of the Jørgen Brønlund Fjord area, Peary Land, North Greenland. Bull. Grønlands geol. Unders. 96, $42 \mathrm{pp}$.

Linnarsson, J. G. O. 1871: Om några försteningar frăn Sveriges och Norges Primordialzon. Öfvers. Kungl. Vetensk. Akad. Förh. 1871(6), 789-796.

Palmer, A. R. \& Peel, J. S. 1979: New Cambrian faunas from Peary Land, eastern North Greenland. Rapp. Grønlands geol. Unders. 91, 29-36.

Peel, J. S. 1982: The Lower Paleozoic of Greenland. Mem. Can. Soc. Petrol. Geol. 8, 309-330.

Repina, L. N. 1979: [Dependence of morphologic features on trilobite mode of life and an evaluation of their significance for the classification of the superfamily Olenelloidea.] Trudy Inst. Geol. Geofiz. sib. Otd. 431, 11-30 [in Russian].

Walcott, C. D. 1888: The stratigraphical succession of the Cambrian faunas in North America. Nature 38, 551 . 